\title{
Wisata Barokah : Alternatif Pembelajaran di Masa Pandemi Covid-19 di RA Al-Ikhlas Mantren
}

\author{
Swasti Maharani ${ }^{1}{ }^{\bowtie}$, Majid $^{2}$, Wachidatul Linda Yuhanna ${ }^{3}$ \\ Pendidikan Matematika, Universitas PGRI Madiun(1) \\ Pendidikan Matematika, Universitas Negeri Gorontalo(2) \\ Pendidikan Biologi, Universitas PGRI Madiun(3) \\ DOI: $10.31004 /$ obsesi.v5i2.992
}

\begin{abstract}
Abstrak
Penelitian ini merupakan penelitian studi kasus di RA Al-Ikhlas Mantren, Magetan, Jawa Timur, Indonesia yang bertujuan untuk mendeskripsikan pembelajaran selama masa pandemi covid-19 yaitu "Wisata Barokah". Teknik pengumpulan data yang dilakukan adalah dokumentasi, wawancara dan observasi. Instrumen yang digunakan oleh peneliti berupa pedoman wawancara dan lembar observasi yang telah divalidasi oleh ahli. Wawancara dilakukan melalui google meeting dan whatsapp. Subjek dalam penelitian ini adalah kepala sekolah, guru pengajar, siswa, dan orang tua siswa RA Al-Ikhlas Mantren sebanyak 15 orang yang diambil secara purposive sampling. Teknik analisis data yang digunakan meliputi tahap pengumpulan data, reduksi data, penyajian data dan kesimpulan. Hasil penelitian menunjukkan bahwa wisata barokah merupakan kegiatan yang dirasa menyenangkan sebagai alternatif pembelajaran di masa pandemi covid-19. Banyak keuntungan bagi guru, siswa, dan orang tua siswa. Kendala yang dihadapi hanya waktu yang terbatas yaitu hanya 4 jam dalam satu minggu dan tidak ada kendala akademis selama berlangsungnya kegiatan wisata barokah.
\end{abstract}

Kata Kunci: wisata barokah; covid-19; alternatif pembelajaran; anak usia dini.

\begin{abstract}
This research is a case study research at RA Al-Ikhlas Mantren, Magetan, East Java, Indonesia, which aims to describe learning during the Covid-19 pandemic, namely "wisata barokah." The data collection techniques used were documentation, interview, and observation. The instruments used by the researcher were interview guides and observation sheets that were validated by experts. Interviews were conducted via google meeting and WhatsApp. Subjects in this study were 15 school principals, teaching teachers, students, and parents of RA Al-Ikhlas Mantren students who were taken by purposive sampling. The data analysis technique used includes data collection stages, data reduction, data presentation, and conclusions. The results showed that wisata barokah was an activity that was felt to be fun as an alternative to learning during the Covid-19 pandemic-many advantages for teachers, students, and parents. The constraints faced are only limited time, which is only 4 hours in one week, and there are no academic obstacles during wisata barokah activities.
\end{abstract}

Keywords: wisata barokah; covid-19; alternative learning; early chidhood.

Copyright (c) 2021 Swasti Maharani, Majid, Wachidatul Linda Yuhanna

$\triangle$ Corresponding author:

Email Address : swasti.mathedu@unipma.ac.id ( Jl. Setiabudi No. 85 Madiun )

Received 22 December 2020, Accepted 4 January 2021, Published 5 January 2021 


\section{PENDAHULUAN}

Pada tahun 2019, seluruh dunia sedang digemparkan dengan munculnya satu virus baru yang mematikan yang disebut dengan covid-19. Virus ini pertama kali ditemukan di kota Wuhan di Cina yang sudah menewaskan $80 \%$ penduduk Wuhan. Virus yang mampu hidup di tubuh manusia bagian kulit ini tentu sangat membahayakan karena sangat mudah untuk berpindah tempat dari sentuhan. Adanya pandemi ini membuat pembelajaran di seluruh dunia berhenti total, tak terkecuali di Indonesia. sebagai solusi yang diambil adalah pembelajaran online. Pembelajaran online didefinisikan sebagai pengalaman transfer pengetahuan menggunakan video, audio, gambar, komunikasi teks, perangkat lunak (Basilaia \& Kvavadze, 2020) dan dengan dukungan jaringan internet (Zhu \& Liu, 2020). Hal ini menjadi trend teknologi digital sebagai ciri khas dari revolusi industri 4.0 untuk menunjang pembelajaran selama masa pandemic COVID-19. Integrasi teknologi dan ragam inovasi ciri dari pembelajaran online (Bao, 2020). Selain itu, yang terpenting adalah kesiapan pendidik dan peserta didik untuk berintereaksi secara online.

Pemerintah di Indonesia memberikan kebijakan untuk menghentikan pembelajaran tatap mula mulai dari pendidikan usia dini sampai perguruan tinggi. Tentunya hal ini memiliki pengaruh yang sangat besar terhadap siswa, terutama anak usia dini. Di usia dini merupakan tahapan emas bagi kinerja otak seseorang dimana pada usia tersebut seseorang anak memerlukan pelayanan lebih, dan langsung dengan tatap muka. Karena anak usia dini merupakan masa emas (golden age) yang hanya ada sekali periode dalam kehidupannya dan tidak dapat diulang kembali (Suhendro \& Syaefudin, 2020).

Pendidikan anak usia dini sangat dibutuhkan bagi masa depan anak, karena pada masa pendidikan ini anak harus mempersiapkan pondasi untuk pendidikan di jenjang selanjutnya (Sudrajat, Agustin, Kurniawati, \& Karsa, 2020). Pembelajaran langsung bagi anak usia dini dapat mencapai seluruh aspek baik aspek kognitif, afektif, maupun prikomotorik. Selain itu anak usia dini cenderung belajar dan didampingi dengan bermain, berinteraksi langsung dengan teman sebaya, dan melakukan berbagai kegiatan untuk mengasah daya cipta dan kreasinya juga. Namun dikarenakan situasi dan kondisi saat ini yaitu pandemic covid-19, para anak usia dini diwajibkan untuk belajar di rumah dengan dibimbing oleh orang tua, dan melakukan pembelajaran dengan daring (dalam jaringan) yang belum pernah dilakukan sebelumnya (Muller et al., 2020; Pamungkas, Marlina, \& Hazizah, 2020; Sadikin \& Hamidah, 2020; Yoshikawa et al., 2020). Anak diharuskan menggunakan HP (Handphone) untuk melakukan pembelajaran yang semestinya belum waktunya dikenalkan pada anak usia dini. Untuk melakukan pembelajaran secara daring, guru harus mempersiapkan segala kebutuhan secara lengkap, mulai dari Laptop atau PC komputer, jaringan internet, bahanbahan ajar yang disesuaikan dengan platform yang digunakan untuk mengajar. Tentunya hal tersebut menjadi kendala bagi sebagian besar guru. Misalnya, belum semua peserta didik memiliki handphone dan masih banyak orang tua sibuk bekerja (Putria, Maula, \& Uswatun, 2020). Sebagian guru juga banyak yang mengalami gagap teknologi (gaptek) terutama guruguru di usia 45 tahun ke atas. Mereka harus bekerja keras untuk mempersiapkan bahan ajar online. Hal tersebut dapat menjadi kendala bagi pembelajaran online atau daring.

Efek yang lebih terasa adalah penggunaan Handphone (HP) bagi anak usia dini. Anak usia dini merupakan anak dengan masa belajar sambil bermain, jika mereka menggunakan HP atau laptop sebagai sarana belajar tanpa didampingi orang tua, anak akan membuka aplikasi-aplikasi lain atau bahkan permainan-permainan di HP atau yang lebih parah mereka bisa mendownloadnya sendiri di playstore. Hal tersebut sangat mungkin terjadi karena anak usia dini masih sangat penasaran dengan hal-hal disekitarnya. Sehingga mereka akan terus dan terus menelusuri isi dari dunia maya yang ada di HP.

Penelitian-penelitian sebelumnya tentang pembelajaran anak usia dini di masa pandemi covid-19 diantaranya yaitu penelitian yang dilakukan oleh Suhendro tahun 2020, yang mendeskripsikan macam-macam pembelajaran daring yang dilakukan pada masa pandemi yaitu siswa belajar dari rumah, belajar secara daring, dan belajar secara luring yaitu 
home visit (kunjungan guru ke rumah siswa). Belajar dari rumah yang dimaksudkan adalah belajar apa saja di rumah dan didampingi orang tua sebagai pengganti peran guru kelas (Ahsani, 2020; Rosali, 2020). Belajar secara daring yang dimaksudkan adalah belajar dalam jaringan/ online (daring) menggunakan media HP atau laptop melalui beberapa platform seperti sosial media, web, dan aplikasi pembelajaran. Pembelajaran daring akan menciptakan pembelajaran yang efektif, karena di dalamnya ada beberapa latihan yang dilakukan siswa seperti beberapa latihan umpan balik yang saling terkait, menggabungkan kolaborasi kegiatan dengan belajar secara mandiri, personalisasi pembelajaran berdasarkan atas kebutuhan anak dan menggunakan simulasi atau permainan. Sehingga seluruh anak akan mendapatkan dampak kualitas yang sama. Dengan adanya situasi pandemi yang belum berakhir maka strategi pembelajaran daring menjadi bagian dari alternatif metode yang ditawarkan kepada siswa sebagai bagian dari penerapan strategi pembelajaran pada masa COVID-19. Proses pembelajaran secara daring ini diharapkan dapat menjadi solusi agar anak didik terhindar dari paparan virus COVID-19. Penelitian serupa juga dilakukan oleh Putria et al. (2020) yang mengungkapkan bahwa pembelajaran daring yang dilakukan untuk anak usia dini kurang efektif. Faktor-faktor pendukung dan penghambat dalam pembelajaran daring diantaranya yaitu ketersediaan HP atau laptop siswa, kuota dan jaringan internet. Sedangkan faktor penghambat belum semua anak memiliki handphone dan masih banyak orang tua sibuk bekerja.

Selain metode daring, metode yang digunakan adalah belajar luring (luar jaringan) atau bisa disebut pembelajaran offline. Metode guru yang digunakan adalah dengan cara kunjungan ke rumah-rumah siswa (home visit). Media pembelajaran yang digunakan berupa modul, buku, lembar kerja, bahan ajar cetak, alat peraga. Guru juga bisa menggunakan alat peraga yang ada disekitar lingkungan rumah. Saat melakukan kunjungan, tentunya guru dan siswa tetap mematuhi protokol kesehatan yang disampaikan oleh pemerintah. Kelebihan dari adanya kunjungan ini adalah guru sedikit banyak dapat mengetahui karakter masing-masing siswanya. Penelitian berikutnya yaitu yang dilakukan oleh Amalina (2020) yang menyebutkan bahwa pembelajaran matematika untuk anak usia dini di masa pandemi covid-19 ini hendaknya merupakan pembelajaran yang menyenangkan yang bisa memotivasi anak dalam mengembangkan diri mereka.

Dari berbagai metode pembelajaran tersebut, tentu guru dan siswa juga mengalami kendala dan jauh lebih sulit daripada pembelajaran langsung di sekolah dengan kebebasan interaksi yang selama ini dilakukan. Menyikapi hal tersebut, pihak RA AL-Ikhlas Mantren menggunakan metode pembelajaran yang diberi nama "Wisata Barokah". Wisata barokah merupakan suatu kegiatan pembelajaran yang diadakan tatap muka namun tetap mematuhi protokol kesehatan dengan waktu hanya 2 jam per hari dan 2 hari dalam satu minggu. Sebelumnya, belum ditemukan metode yang sama di tempat lain. Perbedaan penelitian ini dengan penelitian sebelumnya yaitu penelitian-penelitian sebelumnya mengulas metode alternative pembelajaran adalah metode daring, sedangkan wisata barokah merupakan metode luring yang menyenangkan yang di konsep seperti anak sedang melakukan wisata. Dalam artikel ini, peneliti bermaksud akan mendeskripsikan hal-hal apa saja yang ada pada kegiatan wisata barokah termasuk hal-hal pendukung dan hambatan yang dialami saat melakukan wisata barokah, baik dari sisi Kepala Sekolah, Guru, Siswa, dan Wali Murid.

\section{METODOLOGI}

Penelitian ini merupakan penelitian deskriptif kualitatif yaitu studi kasus. Penelitian ini dilaksanakan di RA Al-Ikhlas Mantren Magetan, Jawa Timur pada bulan Desember 2020 selama 3 minggu. Subjek dalam penelitian ini berjumlah 15 orang yang terdiri dari kepala sekolah, Guru pengajar, wali murid dan siswa RA Al-Ikhlas Mantren. Teknik pengambilan subjek yang digunakan yaitu purposive sampling. Kriteria subjek yang digunakan adalah subjek yang bersedia diwawancarai dan dapat memberikan informasi yang valid. Peneliti menghubungi masing-masing subjek melalui telepon seluler dan meminta ijin untuk 
menjadikan subjek pada masing-masing subjek. Dari 10 guru pengajar hanya 3 yang bersedia untuk memberikan informasi. Dari 122 wali murid hanya 8 orang yang bersedia diwawanacarai. Siswa usia dini yang masuk kriteria ada 3 anak. Adapun instrumen dalam penelitian ini adalah pedoman wawancara dan lembar pengamatan. Adapun beberapa isi dari pedoman wawancara yang dilakukan peneliti dengan guru yaitu apa yang membedakan kegiatan wisata barokah dengan pembelajaran langsung sebelum adanya pandemic covid-19?, Seperti apa langkah-langkah pembelajaran di wisata barokah? Apa yang siswa lakukan mulai dia datang ke sekolah sampai pulang kembali ke rumah? Kendala apa yang dialami guru ketika melaksanakan wisata barokah? Apa keuntungan dari adanya wisata barokah bagi guru dan siswa? Apakah kegiatan wisata barokah yang sudah dilaksanakan cukup efektif sebagai alternatif pembelajaran di masa pandemi ini? Apa yang menjadi harapan Saudara terkait kegiatan wisata barokah ini ke depannya? Bagaimana hasil belajar siswa di masa Pandemi covid 19 ini?. Adapun langkah-langkah penelitian yang dilakukan yaitu pengumpulan data, reduksi data, analisis data, kesimpulan seperti disajikan pada diagram 1.

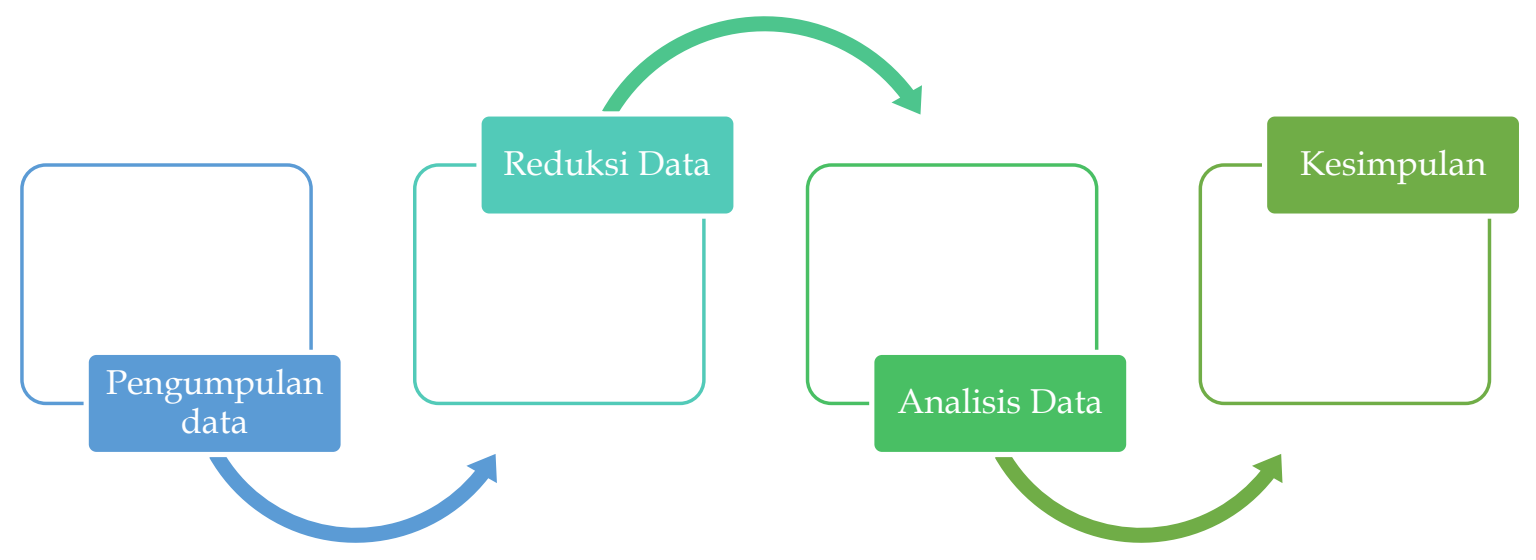

Diagram 1. Tahap Penelitian

Wawancara yang dilakukan adalah wawancara semi terstruktur. Wawancara dilakukan secara daring melalui google meeting dan whatsapp. Sebelum wawancara berlangsung, peneliti menghubungi calon subjek untuk menginformasikan bahwa yang bersangkutan akan dijadikan subjek, peneliti membutuhkan kesediaaan calon subjek untuk memberikan informasi. Wawancara dilakukan oleh peneliti sendiri tanpa enumerator. Wawancara digunakan untuk menggali informasi tentang berbagai hal mengenai adanya wisata barokah. Selain wawancara juga ada observasi atau pengamatan pembelajaran. Peneliti meminta ijin kepada sekolah untuk melakukan pengamatan pembelajaran wisata barokah. Pengamatan dilakukan langsung oleh peneliti dengan dating ke area sekolah saat wisata barokah berlangsung. Peneliti menggunakan lembar observasi berupa catatan lapangan. Tujuan dari adanya observasi ini adalah untuk mengamati bagaimana kegiatan belajar mengajar di wisata barokah yang dilaksanakan oleh guru dan siswa. Setelah dilakukan pengumpulan data, peneliti mereduksi data. Data hasil wawancara di transkrip dan direduksi. Begitu juga data hasil observasi yang berupa catatan lapangan di reduksi dan di analisis. Hasil transkrip wawancara dan catatan tersebut diambil kesimpulannya.

\section{HASIL DAN PEMBAHASAN}

Berdasarkan hasil wawancara dan pengamatan, banyak hal yang dapat dideskripsikan tentang Wisata Barokah, diantaranya yaitu asal-usul wisata barokah, tujuan dan fungsi wisata barokah, kegiatan apa saja yang ada di dalam wisata barokah, keuntungan yang didapat dari adanya wisata barokah baik bagi guru, siswa, dan orang tua siswa. Selain itu juga didapatkan kendala apa saja yang dihadapi dalam pelaksanaan wisata barokah. 


\section{Asal-usul Wisata Barokah}

Pembelajaran daring tentunya juga menimbulkan banyak kendala. Kendala-kendala tersebutlah yang membuat RA Al-Ikhlas berupaya memberikan alternatif pembelajaran yang dapat meminimalisir kendala dalam pembelajaran daring. Pembelajaran daring yang sebelumnya dilakukan adalah guru membentuk grup WhatsApp yang di dalamnya termasuk wali murid masing-masing kelas. Tugas untuk siswa dikirim ke dalam grup tersebut dan dikumpulkan melalui grup tersebut juga. Keputusan ini diambil mengingat keterbatasan guru dan orang tua siswa dalam mengakses aplikasi pembelajaran dan menurut guru anak usia dini membutuhkan pelayanan lebih secara langsung dan sulit untuk melalui aplikasi e-learning dan sejenisnya. Hal tersebut sesuai dengan hasil penelitian yang dilakukan oleh Nurdin \& Anhusadar (2021), dimana masih banyak pendidik PAUD yang belum mahir menggunakan aplikasi pembelajaran online.

Setelah dilakukan evaluasi, metode tersebut menimbulkan banyak kendala. Adapun kendala-kendala yang dialami oleh para guru, siswa dan wali murid saat pembelajaran daring diantaranya yaitu waktu pengiriman tugas pagi pada HP orang tua tidak dapat langsung disampaikan kepada anak karena sebagian besar orang tua tetap bekerja di masa pandemi (Putria et al., 2020), sehingga anak sendiri mengalami kesulitan mengerjakan, ketika sore hari orang tua pulang kerja merasa lelah harus memberikan bimbingan belajar kepada anak dan kesulitan dalam memberikan metode yang sesuai untuk anak. Disamping itu, ketika anak menggunakan HP orang tua untuk belajar sebagian besar menggunakan waktu belajar hanya sebentar namun banyak menggunakan HP untuk bermain. Hal ini membuat orang tua/wali merasa kesulitan melarang anak menggunakan HP untuk bermain dan keterbatasan fasilitas yang diberikan oleh orang tua (Obiakor \& Adeniran, 2020). Selain itu juga yang menjadi kendala adalah hasil belajar anak tidak murni $100 \%$ karena ada bantuan orang tua karena ada beberapa orang tua yang merasa tidak sabar dalam membimbing belajar anak sehingga sulit melakukan penilaian. Orang tua merasa kesulitan menggantikan peran guru (Oktaria \& Putra, 2020). Banyak juga orang tua yang mengeluh karena meningkatknya biaya kuota internet (Sharma \& Jones, 2019). Para guru dan pemangku kebijakan di RA AL-Ikhlas merasa pembelajaran masih belum baik dan masih banyak kendala.

Memasuki bulan Juni 2020, dimana aturan pemerintah sudah memberlakukan situasi "New Normal" dimana aktivitas manusia sudah diperbolehkan namun harus mematuhi protokol kesehatan. Berdasarkan evaluasi sebelumnya, sekolah mengubah model pembelajaran dengan memberikan tugas berupa buku ataupun lembar kerja yang diambil oleh orang tua secara bergantian di salah satu rumah guru, terjadwal di lokasi yang berbedabedamenyesuaikan kondisi tempat tinggal terdekat anak. Pengambilan lembar tugas ini tetap dikombinasi dengan informasi bagi orang tua melalui whatsapp, tugas anak sudah bentuk lembar kerja dan fungsi grup whatsapp untuk mengingatkan kembali orang tua tugas belajar siswa.

Metode pengambilan tugas ini dilakukan sampai akhir tahun pelajaran. Setelah berakhir tahun pelajaran dilakukan evaluasi melalui wawancara dengan wali murid mengenai kesulitan dalam metode pengambilan tugas, dan beberapa pernyataan wali murid diantaranya metode pengambilan tugas secara umum dapat mengurangi keinginan anak untuk menggunakan HP karena tidak setiap saat diberikan, namun orang tua kadang harus bolak-balik mengambil dan mengumpulkan tugas, padahal rumah tinggal jauh dan bekerja, orang tua mengalami kesulitan dalam memahami tugas anak karena dalam lembar kerja anak tidak memuat langkah-langkah dalam mengajarkan sebuah materi sehingga orang tua mempersepsikan masing-masing cara mengajarkan materi belajar anak, guru masih mengalami kesulitan dalam menilai hasil belajar anak karena beberapa orang tua ada yang tidak tepat waktu dalam pengambilan tugas anak. Berdasarkan hasil wawancara, evaluasi yang dilakukan sekolah menyimpulkan metode pengambilan tugas lebih baik, namun masih banyak kendala yang dihadapi. Hal ini menunjukkan bahwa merupakan tantangan besar 
dengan situasi dan kondisi yang seperti ini untuk mempertahankan kelas tetap aktif padahal sekolah tutup (Herliandry, Nurhasanah, Suban, \& Kuswanto, 2020).

Memasuki Tahun Ajaran Baru 2020/2021 sekolah terus berupaya mencari metode yang tepat dalam menyampaikan materi belajar pada anak. Tantangan baru yang dihadapi sekolah adalah siswa baru yang belum mengenal lingkungan sekolah. Sekolah tetap berupaya mencari inovasi dalam melaksanakan pembelajaran.

Untuk mendekatkan sekolah dan siswa dilaksanakan kegiatan home visit. Dalam kegiatan home visit beberapa anak dari lingkungan terdekat dikumpulkan dalam satu lokasi dengan standar prookol kesehatan covid-19. Pada akhir bulan Juli 2020 kembali dilaksanakan evaluasi kegiatan home visit. Berdasarkan hasil evaluasi yang disampaikan oleh guru diantaranya jumlah murid RA Al-Ikhlas seluruhnya ada 155 anak yang terbagi lebih dari 10 desa. Hal ini menjadi kesulitan tersendiri bagi guru untuk menjangkau lokasi home visit, kelompok anak yang dibagi juga mengalami kesulitan mencari lokasi yang ditentukan, kesulitan orang tua mengatur waktu mengantar dan menjemput anak.

Berdasarkan hasil wawancara, setelah evaluasi, kegiatan home visit masih memiliki banyak kendala dan orang tua banyak yang mengeluh.

Sekolah terus berusaha mencari cara agar layanan yang diberikan dapat lebih optimal pada siswa. Berdasarkan hasil rapat guru, kepala sekolah, pengurus yayasan, diputuskan untuk menawarkan pada orang tua/wali murid untuk dilaksanakan suatu layanan kegiatan yang dapat bersinggungan dengan anak untuk membantu model pembelajaran daring. Kegiatan ini diberi nama "WISATA BAROKAH" yang dilaksanakan di lingkungan RA AlIkhlas Mantren. Nama wisata barokah ini dimaksudkan adalah anak-anak usia dini dapat melakukan wisata sambil belajar, wisata yang dimaksud adalah wisata di lingkungan sekolah RA Al-Ikhlas Mantren dengan teman-teman, dan kata barokah berarti berkah, dengan maksud harapannya kegiatan ini dapat menimbulkan efek yang positif dan mendapat berkah dari Allah SWT. Pertimbangan dalam melaksanakan kegiatan ini adalah area lingkungan RA Al-Ikhlas yang tidak digunakan untuk pembelajaran tatap muka karena sekolah ditutup selama pandemi, adanya celah bahwa kegiatan wisata diperbolehkan selama mematuhi standar protokol kesehatan covid-19, sarana dan prasarana standar protokol kesehatan telah tersedia di RA Al-Ikhlas diantaranya cek suhu, sarana cuci tangan, penyediaan hand sanitaizer, sterilisasi secara berkala dan banner-banner yang telah terpasang berisi himbauan protokol kesehatan di masa pandemi, ada pemandu kegiatan yaitu guru-guru yang telah selesai mengiriman panduan tugas daring, kegiatan dilakukan dengan dibagi-bagi dalam kelompok untuk menghindari kerumunan, kegiatan ini tidak wajib hanya layanan yang diberikan kepada orang tua yang menginginkan layanan tambahan bagi anaknya. Apabila tidak menghendaki hanya mengikuti pembelajaran daring melalui pengambilan tugas dan panduan dikirim melalui WA. Hasil rapat unsur guru, kepala sekolah dan pengurus yayasan ini disosialisasikan dalam kegiatan Pertemuan Orang Tua dan Guru ( POMG ) yang dilaksakan pada hari Sabtu, 18 Agustus 2020 bertempat di SDIT Al Ikhlas pukul 08.00 sampai pukul 10.00 WIB. Dari hasil pertemuan antara guru dan orang tua dicapai kesepakan melaksanakan kegiatan "WISATA BAROKAH" dengan standar protokol kesehatan covid-19.

\section{Fungsi dan Tujuan Wisata Barokah}

Adapun fungsi dari wisata barokah berdasarkan hasil wawancara dengan kepala sekolah adalah memberikan layanan tambahan dimasa pandemi akibat sekolah tatap muka yang ditutup. Tujuan kegiatan wisata barokah agar sekolah menjadi lebih dekat dengan peserta didik, mengawal kegiatan baca Al-Qur'an anak dan memantapkan pembentukan kepribadian muttaqin sesuai program sekolah. Selain itu dengan adanya wisata barokah guru dapat mengetahui karakter dari peserta didiknya dan menilai kegiatan fisik dengan nyata.

Sampai sejauh ini, wisata barokah berjalan dengan lancar dan minim kendala. Hal tersebut sesuai dengan cuplikan wawancara peneliti dengan salah seorang guru RA Al-Ikhlas Mantren berikut "Alhamdulillah kegiatan berjalan lancar. Kegiatan wisata barokah ini mendapatkan 
tanggapan positif dari wali murid, bahkan antusiasme wali murid sangat bagus. Disamping itu, anakpun semangat mengikuti kegiatan wisata barokah."

Berdasarkan hasil wawancara tersebut, sedikit banyak tujuan wisata barokah terpenuhi. Anak usia dini memang harus diberikan layanan khusus dan langsung, karena mereka masih dalam tahap meniru, rasa ingin tahu yang tinggi, dan mencetak kepribadian diri (Smith \& Arts, 2017). Jika hanya belajar dengan online dan daring, anak-anak usia dini kemungkinan besar akan kehilangan "golden age" mereka (Dere, 2019). Hal ini tentunya akan sangat memengaruhi banyak aspek dalam kehidupan mereka kelak.

\section{Kegiatan yang ada dalam wisata barokah}

Semua kegiatan yang ada di wisata barokah semua tetap mematuhi protokol kesehatan yang dihimbau oleh pemerintah.

Standar protokol kesehatan yang dilakukan dalam kegiatan wisata barokah yaitu memasuki area wisata barokah Al Ikhlas harus lolos standar cek suhu badan tidak lebih dari $37^{\circ}$ Celsius, anak harus dalam kondisi sehat jasmani, tidak sedang dalam kondisi demam, batuk, pilek, sesak nafas, wajib memakai masker dan ditambah face shield selama berada di area wisata barokah, setelah lolos standar cek suhu badan langsung cuci tangan di tempat yang telah disediakan, mengikuti kegiatan wisata barokah dengan dipandu oleh pemandu wisata barokah dalam waktu yang ditentukan, dilarang berkerumun dan selalu menjaga jarak dengan berada di posisi berdiri/duduk yang telah ditentukan dengan tanda yang diberikan pada area wisata, selama berkegiatan pemandu secara kontinyu memberikan hand sanitaizer untuk menjaga sterilisasi anak, secara berkala dilakukan penyemprotan desinfektan untuk pencegahan covid 19, bagi anak yang baru saja bepergian dari kota/wilayah yang menjadi zona merah tidak diperkenankan mengikuti kegiatan selama sepekan hingga dipastikan tidak timbul gejala covid-19, bagi anak yang dilingkungan sekitarnya terdapat pasien positif covid19 tidak diperkenankan mengikuti kegiatan wisata barokah selama satu pekan hingga dipastikan tidak timbul gejala covid-19.

Kegiatan dilakukan di sekolah ini dimulai pukul 07.30 sampai dengan 10.00 WIB dan dilakukan setiap dua hari di setiap minggunya. Setiap guru memiliki peran masing-masing dalam melayani siswa di wisata barokah. Saat masuk gerbang sekolah siswa sudah di jamu oleh satu guru yang bertugas mengecek suhu badan siswa, kemudian anak menunggu jam kegiatan masuk dengan bergantian membaca (dalam istilah lain bermain huruf) masuk kelas untuk mengikuti serangkaian kegiatan wisata barokah mulai dari jasmani, cuci tangan pakai sabun, berdo'a, hafalan, mengaji, membaca secara klasikal dan materi pembelajaran yang menunjang 10 aspek pengembangan dalam kurikulum. Mengaji dilaksanakan secara bergantian. Istirahat makan bekal masing-masing dan tetap dalam posisi d tempat duduk masing-masing. Tak lupa cuci tangan pakai sabun. Lalu berdo'a pulang. Sebelum pulang, tangan anak diberi hand sanitizer karena tangan sangat rentan menjadi tempat bersarangnya virus dan bakteri (Solopos.com, 2020).

Kegiatan yang melatih jasmani siswa misalnya siswa diminta berlari zig-zag melewati rintangan. Rintangan yang digunakan adalah botol plastik. Kegiatan ini berguna untuk menunjang perkembangan fisik anak. Karena pada usia dini, pendidikan yang diberikan harus dapat memastikan stimulasi yang berbeda pada anak, mengarah pada perkembangan intelektual, emosional, sosial, dan fisik setiap anak (Parliament, 2010). Kegiatan jasmani tetap mematuhi standar protokol kesehatan yaitu siswa menggunakan masker dan menjaga jarak serta tidak saling bersentuhan. Kegiatan ini dimaksudkan agar melatih kelincahan, kelenturan, dan keseimbangan anak. Adapun kegiatan jasmani disajikan pada Gambar 1.

Kegiatan selanjutnya adalah mencuci tangan memakai sabun sebelum masuk ke dalam kelas. Kegiatan ini dimaksudkan untuk menjaga kebersihan tangan siswa agar terhindar dari bahaya virus covid-19, karena virus akan mati jika terkena sabun. Air dan menggosok tangan dengan sabun sangatlah penting karena kombinasi ini menciptakan lebih banyak gelembung sabun, yang mengganggu ikatan kimia yang memungkinkan bakteri, virus, dan kuman 
lainnya menempel di permukaan (Bramasta, 2020). Adapun kegiatan mencuci tangan dengan sabun disajikan pada Gambar 2.

Kegiatan berikutnya yaitu berdoa bersama. Hal ini dimaksudkan agar siswa terbiasa melakukan doa sebelum melakukan aktivitas apapun. Disini siswa juga diberi pengertian mengapa harus selalu menjaga jarak antar teman dan tidak saling bersentuhan. Hal ini dimaksudkan agar anak mengerti dan memahami sebagai bentuk ketercapaian indicator perkembangan kognitif siswa (Hewi \& Asnawati, 2020). Di dalam kelas anak diberikan tempat duduk yang nyaman dan tetap berjarak antara siswa satu dengan yang lainnya. Adapun kegiatan berdoa bersama disajikan pada Gambar 3.

Setelah doa bersama, siswa diajak dan dipandu oleh guru untuk menghafalkan hadits dan surat-surat pendek. Kegiatan tersebut dilakukan karena mengingat bahwa anak usia dini merupakan sosok yang penuh potensi, memiliki karakteristik yang unik, rasa ingin tahu yang tinggi, serta memiliki daya ingat yang tajam. Haditś-haditś tersebut dapat diperkenalkan sejak usia dini, dimulai dari membaca, menghafal hingga mengamalkannya pada kehidupan seharihari (Malikah \& Rohinah, 2019). Disamping itu kegiatan tersebut dilakukan dikarenakan krisis moral yang menimpa Indonesia saat ini berawal dari lemahnya penanaman nilai agama terhadap anak usia dini (Nuryati, 2017) sehingga perlu penanaman agama sejak dini kepada anak. Hadits yang dikenalkan untuk anak RA tingkat A (tingkat pertama) ada 7 hadits, diantaranya hadits kasih sayang, hadits persaudaraan, hadits berbuat baik, hadits keindahan, hadits kebersihan, hadits jangan suka marah, dan hadits menyebarkan salam. Adapun kegiatan tersebut disajikan pada Gambar 4.

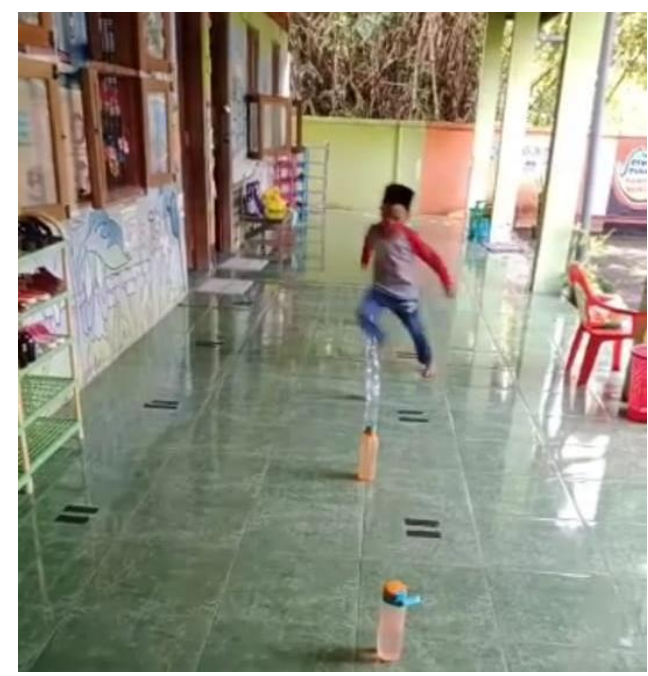

\section{Gambar 1. Kegiatan jasmani berlari zig-zag melewati rintangan}

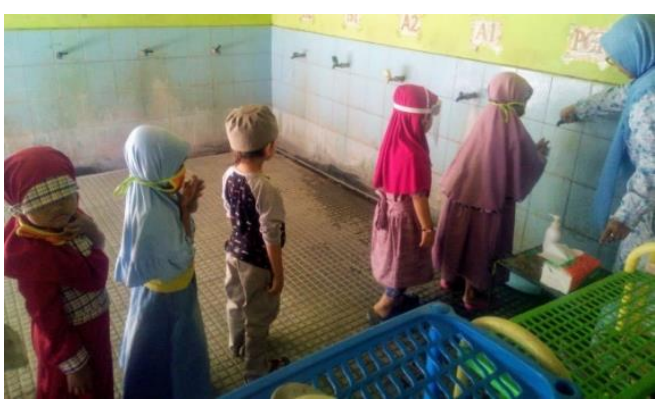

Gambar 2. Anak antri dan jaga jarak saat mencuci tangan memakai sabun sebelum masuk ke dalam kelas wisata barokah

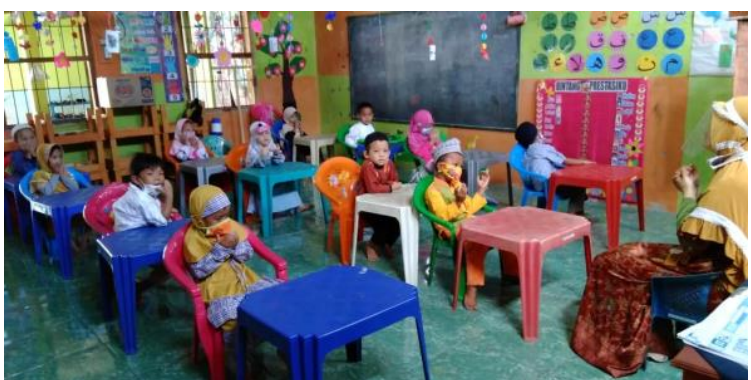

Gambar 3. Kegiatan berdoa bersama 


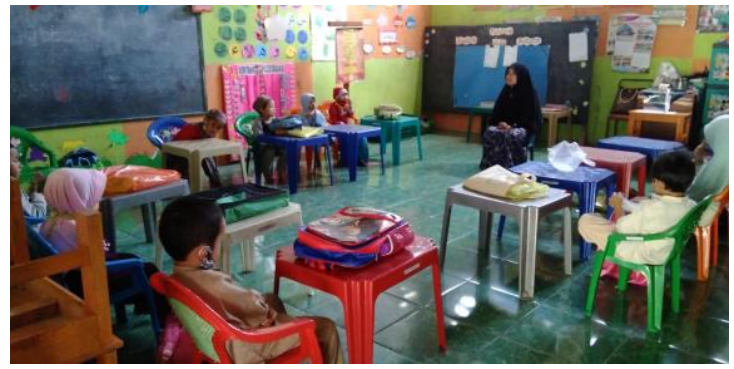

Gambar 4. Kegiatan hafalan hadits dan surat pendek dipandu guru saat wisata barokah

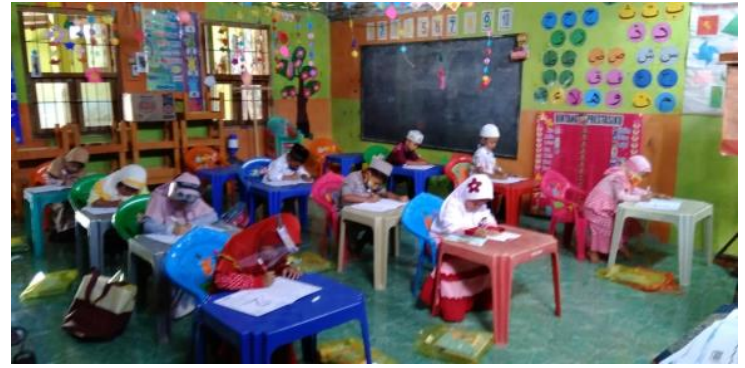

Gambar 5. Kegiatan menggambar dan menulis huruf dan angka untuk menciptakan kreatifitas anak

Selanjutnya, serangkaian kegiatan wisata barokah yang dapat meningkatkan kreatifitas siswa yaitu menggambar sesuka hati siswa, menulis huruf dan angka. Kreativitas merupakan hal mendasar dalam kurikulum PAUD dan dapat didefinisikan sebagai prosedur untuk menciptakan sesuatu yang orisinal. Guru PAUD harus memberi anak materi untuk memicu imajinasi mereka, harus memberikan kesempatan untuk berimajinasi dan menjelaskan ide-ide mereka, harus menghargai individualitas anak, dan harus mendorong sudut pandang mereka yang berbeda. Mereka juga harus mendorong anak-anak untuk berpartisipasi dalam permainan kreatif, harus peduli dengan produk baru anak-anak, dan menghargai mereka. Apalagi kreativitas anak harus diapresiasi, dan anak harus diberi kepercayaan (Dere, 2019). Disamping itu pemberian tugas untuk menulis huruf dan angka merupakan kegiatan siswa yang dapat meningkatkan kognitif, afektif dan psikomotorik seperti yang dilakukan saat pembelajaran langsung (Sudrajat et al., 2020). Adapun kegiatan tersebut disajikan pada Gambar 5.

Kegiatan selanjutnya adalah latihan sholat, dan sholat yang dilatihkan adalah sholat dhuha. Guru berada di depan dan menjadi panutan bagi siswa. Kegiatan sholat dilakukan dengan tetap mematuhi protocol kesehatan yang dihimbau pemerintah yaitu memakai masker, menjaga jarak, tidak bersentuhan, dan menggunakan sajadah milik siswa sendirisendiri. Sholat merupakan prinsip dasar agama Islam dan merupakan amalan penting yang harus dilakukan pada waktu dan kondisi tertentu, mengikuti urutan. Gerakan-gerakan seseorang ketika sholat seperti berdiri (Qiyam), rukuk, sujud dan duduk tasyahud, semuanya memiliki hubungan yang kuat dengan spiritual, mental dan fisik. Manfaat gerakan tertentu berasal dari posisi yang benar, lamanya posisi dipegang dan dengan pengucapan yang cermat dan benar (Bhat, Murtaza, Sharique, \& Jabin, 2016). Sehingga kegiatan ini sangat bermanfaat bagi anak jika diajarkan sejak dini. Adapun kegiatan latihan sholat disajikan pada Gambar 6. Berikut

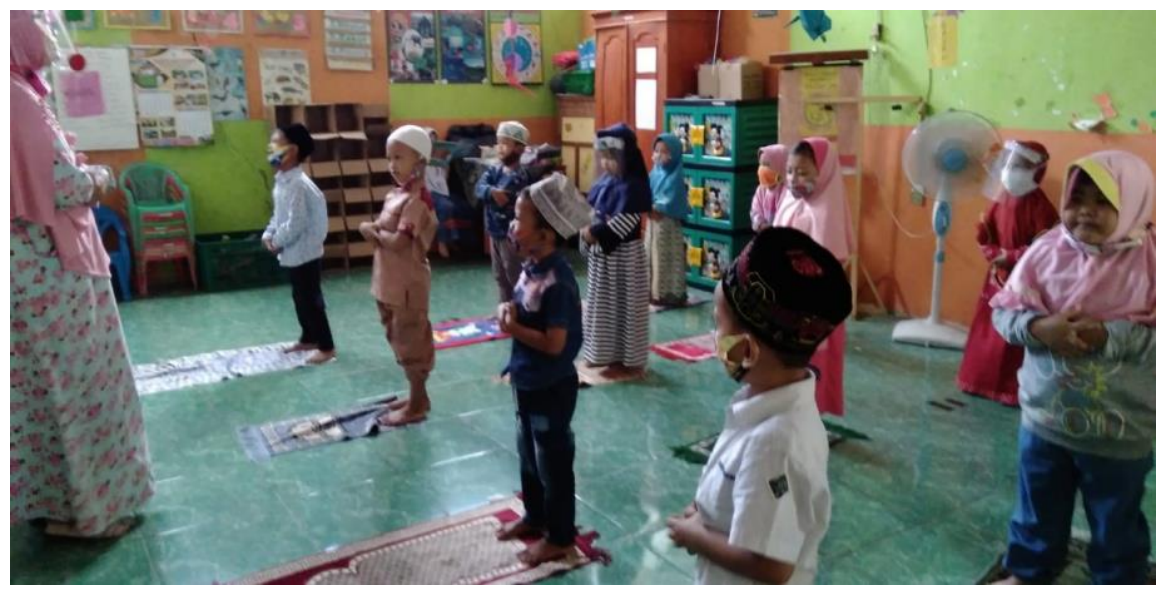

Gambar 6. Latihan sholat dhuha 


\section{Keuntungan adanya Wisata Barokah}

Secara umum setelah dilakukan evaluasi dalam 3 bulan pelaksanaan kegiatan wisata barokah yaitu dilaksanakan evaluasi bersama pada bulan November 2020, secara umum orang tua memberikan respon yang positif pada sekolah karena layanan wisata barokah ini dapat membantu orang tua dalam melaksanakan pembelajaran daring selama masa pandemi. Menurut penuturan orang tua kegiatan wisata barokah ini dapat membantu mengurangi tingkat kejenuhan anak karena tidak ada kegiatan di rumah. Selain itu, orang tua dimudahkan dalam pembimbingan anak di rumah. Anak dirumah juga mengerjakan PR yang dibawa dari wisata barokah, sehingga waktu mereka untuk bermain menjadi minimal.

Dari sisi guru adanya kegiatan wisata barokah juga menjadi aktivitas yang menyenangkan. Walaupun ada keterbatasan interaksi dengan anak namun dapat membantu mempermudah guru menyampaikan pesan karakter kepada anak akar mencapai perkembangan yang lebih baik sesuai 10 program pengembangan yaitu Aqidah islamiah, akhlakul karimah, kedisiplinan, pengendalian emosi, interaksi sosial, bahasa, daya pikir, daya cipta, keterampilan dan jasmani. Apabila hanya mengandalkan daring saja akan sulit melakukan penilaian ketercapaian. Wisata barokah cukup efektif digunakan sebagai alternatif pembelajaran di RA Al-Ikhlas Mantren.

Dari sisi anak merasa senang dapat bertemu dengan teman sebaya walaupun dalam interaksi yang terbatas. Dari sini wisata barokah memberikan manfaat yang cukup besar bagi interaksi sosial anak dengan teman-teman sebayanya. Anak tidak hanya berdiam diri dirumah dan kurang mengenal teman sekolahnya. Interaksi sosial adalah salah satu aspek terpenting dari setiap perkembangan anak (Johnson, 2003; Kington, Gates, \& Sammons, 2013). Manfaatnya akan memiliki efek seumur hidup pada anak. Selain itu wisata barokah mengurangi kejenuhan pada anak. Masa pandemi yang mengharuskan anak berada di rumah terus membuat mereka jenuh.

\section{Kendala yang dihadapi}

Kendala selama kegiatan tidak banyak, bahkan belum ditemukan kendala yang berarti. Orang tua banyak yang mengharapkan agar jam layanan wisata barokah dapat ditambah hari/jamnya namun mengingat situasi pandemi hal ini belum dapat diwujudkan. Hal ini didasari oleh wawancara dengan para wali murid. Berikut cuplikan hasil wawancara dengan wali murid, "waktunya sangat kurang, saya berharap ke depannya waktu yang digunakan untuk wisata barokah ditambah lagi agar anak lebih optimal belajarnya."

Kendala yang dihadapi guru yaitu ada anak yang kurang begitu diperhatikan oleh orang tuanya dirumah yang menyebabkan kegiatan di wisata barokah sedikit terhambat karena anak yang tidak membawa peralatan wisata barokah. Kendala lain yaitu waktu. Waktu kegiatan wisata barokah terasa kurang karena anak hanya mendapatkan 2kali pertemuan saja tiap minggunya. Sedangkan kendala yang dihadapi oleh wali murid adalah ada pada masingmasing anaknya. Ada anak yang susah diminta memakai masker misalnya. Kemudian kendala lain bagi orang tua adalah waktu. Orang tua yang notabene bekerja di kantor kesulitan untuk menjemput anak karena anak pulang pukul $10.00 \mathrm{WIB}$, dimana orang tua jam istirahat kantor pukul 12.00 WIB. Berdasarkan kendala-kendala diatas, tidak ditemukan kendala akademis dalam pelaksanaan wisata barokah.

\section{SIMPULAN}

Wisata barokah merupakan pembelajaran alternatif di masa pandemi covid-19 yang menyenangkan bagi anak. Keuntungannya, sekolah dapat tetap melaksanakan tanggung jawab memberikan pelayanan penuh kepada anak dan orang tua, guru dapat mengenal karakter siswa dan dapat dengan mudah memberikan penilaian kepada siswa, Guru tidak perlu repot-repot membuat bahan ajar online, siswa tetap dapat menerima pelajaran langsung dengan mematuhi protokol kesehatan dan dapat berinteraksi dengan teman-teman sebayanya sehingga memberikan dampak positif bagi kehidupan sosial mereka. 


\section{UCAPAN TERIMA KASIH}

Terima kasih penulis ucapkan kepada seluruh pihak RA Al-Ikhlas Mantren yang telah meluangkan waktunya untuk memberikan informasi tentang wisata barokah dan semua pihak yang telah membantu pelaksanaan penelitian dan penulisan artikel ini. Tidak lupa ucapan terima kasih kepada editor dan reviewer Jurnal Obsesi yang sudah memberikan kesempatan sehingga jurnal bisa untuk diterbitkan.

\section{DAFTAR PUSTAKA}

Ahsani, E. L. F. (2020). Strategi Orang Tua dalam Mengajar dan Mendidik Anak dalam Pembelajaran At The Home Masa Pandemi Covid-19. Jurnal Al_Athfal, 3(1), 37-46.

Amalina, A. (2020). Pembelajaran Matematika Anak Usia Dini di Masa Pandemi COVID-19 Tahun 2020. Jurnal Obsesi: Jurnal Pendidikan Anak Usia Dini, 5(1), 538. https:// doi.org/10.31004/obsesi.v5i1.592

Bao, W. (2020). COVID -19 and online teaching in higher education: A case study of Peking University . Human Behavior and Emerging Technologies, 2(2), 113-115. https:// doi.org/10.1002/hbe2.191

Basilaia, G., \& Kvavadze, D. (2020). Transition to Online Education in Schools during a SARSCoV-2 Coronavirus (COVID-19) Pandemic in Georgia. Pedagogical Research, 5(4). https:// doi.org/10.29333/pr/7937

Bhat, R. A., Murtaza, S. T., Sharique, M., \& Jabin, F. (2016). Unity of Health Through Yoga and Islamic Prayer ' Salah ' Unity of Health Through Yoga and Islamic. Academic Sport Scholar, 3(October 2014), 1-6.

Bramasta, D. B. (2020). Bagaimana Sabun, Hand Sanitizer, dan Air Hangat Mampu Melawan Covid-19? Kompas.Com, pp. 1-7. Retrieved from https:// www.kompas.com/tren/read/2020/03/25/090000265/bagaimana-sabunhand-sanitizer-dan-air-hangat-mampu-melawan-covid-19?page=all

Dere, Z. (2019). Investigating the creativity of children in early childhood education institutions. Universal Journal of Educational Research, 7(3), 652-658. https:// doi.org/10.13189/ujer.2019.070302

Herliandry, L. D., Nurhasanah, N., Suban, M. E., \& Kuswanto, H. (2020). Pembelajaran Pada Masa Pandemi Covid-19. JTP - Jurnal Teknologi Pendidikan, 22(1), 65-70. https:// doi.org/10.21009/jtp.v22i1.15286

Hewi, L., \& Asnawati, L. (2020). Strategi Pendidik Anak Usia Dini Era Covid-19 dalam Menumbuhkan Kemampuan Berfikir Logis. Jurnal Obsesi : Jurnal Pendidikan Anak Usia Dini, 5(1), 158. https://doi.org/10.31004/obsesi.v5i1.530

Johnson, C. D. (2003). The role of child development and social interaction in the selection of children's literature to promote literacy acquisition. Early Childhood Research and Practice, 5(2).

Kington, A., Gates, P., \& Sammons, P. (2013). Development of social relationships, interactions and behaviours in early education settings. Journal of Early Childhood Research, 11(3), 292-311. https:// doi.org/10.1177/1476718X13492936

Malikah, F., \& Rohinah. (2019). Penerapan Metode Gerakan untuk Menghafal Hadis pada Anak. Golden Age : Jurnal Ilmiah Tumbuh Kembang Anak Usia Dini, 4(1), 25-34.

Muller, A. E., Hafstad, E. V., Himmels, J. P. W., Smedslund, G., Flottorp, S., Stensland, S. Ø., ... Vist, G. E. (2020). The mental health impact of the covid-19 pandemic on healthcare workers, and interventions to help them: A rapid systematic review. Psychiatry Research, 293(July), 113441. https:/ / doi.org/10.1016/j.psychres.2020.113441

Nurdin, \& Anhusadar, L. O. (2021). Efektivitas Pembelajaran Online Pendidik PAUD di Tengah Pandemi Covid 19. Jurnal Obsesi : Jurnal Pendidikan Anak Usia Dini, 5(1), 686697.

Nuryati. (2017). Pembelajaran Hadis untuk Anak Usia Dini. Proceedings of The 2nd Annual Conference on Islamic Early Childhood Education, 2, 273-284. 
DOI: 10.31004/obsesi.v5i2.992

Obiakor, T., \& Adeniran, A. (2020). Covid-19: Impending Situation Threatens To Deepen Nigeria' S Education Crisis. In Center For The Study Of The Economies Of Africa.

Oktaria, R., \& Putra, P. (2020). Child Education in the Family As an Early Childhood. Jurnal Ilmiah PESONA PAUD, 7(1), 41-51.

Pamungkas, A. H., Marlina, S., \& Hazizah, N. (2020). Digital Press Social Sciences and Humanities Implementation of Early Childhood Education Policy in The Pandemic of COVID-19 In Indonesia Proceeding of The Non-Formal Education International Conference 2020 Implementation of Early Childhood Education Polic.

Parliament, S. (2010). Steering Documents and Types of Activities.

Putria, H., Maula, L. H., \& Uswatun, D. A. (2020). Analisis Proses pembelajaran Dalam Jaringan (DARING) Masa Pandemi COVID-19 pada Guru Sekolah Dasar. Jurnal Basicedu, 4(4), 861-872. https:// doi.org/10.31004/basicedu.v4i4.460

Rosali, E. S. (2020). Aktifitas Pembelajaran Daring Pada Masa Pandemi Covid -19 Di. Geography Science Education Journal (GEOSEE), 1(1), 21-30.

Sadikin, A., \& Hamidah, A. (2020). Pembelajaran Daring di Tengah Wabah Covid-19. Biodik, 6(2), 109-119. https:// doi.org/10.22437/bio.v6i2.9759

Sharma, R. S., \& Jones, K. A. (2019). An experiment in blended learning: higher education without lectures. International Journal of Digital Enterprise Technology, 1(3), 241. https://doi.org/10.1504/ijdet.2019.10019066

Smith, K., \& Arts, M. E. A. F. (2017). New Materials for Teaching Computational Thinking in Early Childhood Education. Massachusetts Institute of Technology.

Solopos.com. (2020). Lindungi Diri Dari Virus Corona, Sabun Atau Hand Sanitizer Lebih Ampuh Mana? Solopos.Com. Retrieved from https://www.solopos.com/lindungi-diridari-virus-corona-sabun-atau-hand-sanitizer-lebih-ampuh-mana-1052652

Sudrajat, C. J., Agustin, M., Kurniawati, L., \& Karsa, D. (2020). Strategi Kepala TK dalam Meningkatkan Mutu Pendidikan pada Masa Pandemi Covid 19. Jurnal Obsesi : Jurnal Pendidikan Anak Usia Dini, 5(1), 508. https:/ / doi.org/10.31004/obsesi.v5i1.582

Suhendro, E. (2020). Strategi Pembelajaran Pendidikan Anak Usia Dini di Masa Pandemi Covid-19. Jurnal Golden Age, 5(3), 133-140. Retrieved from http://ejournal.uinsuka.ac.id/tarbiyah/index.php/goldenage/article/view/3394/1884

Suhendro, E., \& Syaefudin, S. (2020). Nilai-Nilai Kemanusian Dalam Pendidikan Anak Usia Dini Inklusi. JEA (Jurnal Edukasi AUD), 6(1), 1. https:/ / doi.org/10.18592/jea.v6i1.3430

Yoshikawa, H., Wuermli, A. J., Britto, P. R., Dreyer, B., Leckman, J. F., Lye, S. J., ... Stein, A. (2020). Effects of the Global Coronavirus Disease-2019 Pandemic on Early Childhood Development: Short- and Long-Term Risks and Mitigating Program and Policy Actions. Journal of Pediatrics, 223(May), 188-193. https://doi.org/10.1016/j.jpeds.2020.05.020

Zhu, X., \& Liu, J. (2020). Education in and After Covid-19: Immediate Responses and LongTerm Visions. Postdigital Science and Education, 2(3), 695-699. https://doi.org/10.1007/s42438-020-00126-3 